Hospital (U.C.H.), Ibadan, on 23 April 1968, from the psychiatric unit on account of increasing drowsiness and the finding on physical examination of bilateral papilloedema and left hemiparesis. She had been under treatment for paranoid schizophrenia since September 1967.

She was first seen in this hospital in April 1961 after miscarrying a 10-week pregnancy, her second within two years. Her outside doctor attributed these to inadequate rest in the early months of pregnancy, "due to her high sense of duty." Her first child was delivered normally at home in 1959. There was no record of her postnatal state. She delivered her second child normally in April 1964 five weeks premature. Six weeks later she reluctantly resumed duty, and for the first time in her life suffered "a terrible headache."

Since then she has had recurrent attacks of frontal headaches weekly. She was treated for migraine and obtained minimal relief for four weeks. In January 1965, on account of the increasing severity of headaches and the occasional association of vomiting, she attended the medical outpatient department of U.C.H., Ibadan. She was found to be bradykinetic (due to repeated sedation), otherwise there was no abnormality on physical examination. A diagnosis of depression was made. Two days later she asked for her discharge and she was sent home on meprobamate.

In September 1967 she was admitted into the psychiatric unit on account of headaches, loss of memory, and talkativeness. Her usual frontal headaches became obstinate, and at their severest she vomited easily. Early in the year she had bost her job as secretary when the decay in her memory became manifest, a feature which later became progressive. She slept a lot, and, when not sleeping, talked a lot. She was admitted, and treatment was instituted for paranoid schizophrenia. There were frequent reports of her suddenly and spontaneously becoming stuporose and dribbling saliva.

It became obvious that an organic lesion was probably responsible for her strange behaviour. Radiography of skull showed some erosion of her dorsum sella. On the carotid angiograms the right middle cerebral artery was displaced medially and upwards by a mass in the middle-third of the sphenoidal wing. The vascular flush suggested a meningioma. A right temporal osteoplastic craniotomy was performed and a large discrete meningioma, about $5 \mathrm{~cm}$. by $4 \mathrm{~cm}$. by $6 \mathrm{~cm}$., was removed from the sphenoidal wing. It was highly cellular and relatively vascular and histological sections later showed it to be angioblastic in nature. The patient made a satisfactory recovery and was discharged home from hospital 18 days after her operation. Her headaches ceased, she became mentally clear, and talked freely without lack of wit. Her memory improved significantly, and an intelligence test performed on her while on holiday in England placed her Wechsler scale at 130

Of particular interest was the onset of the patient's symptoms six weeks after the delivery of her second child. Examples have been described of meningioma which showed accelerated development during pregnancy, and in each case the meningioma has been suprasellar, parasellar, or at the sphenoida wing in location. Sensitivity to hormona effects and increase in physical size of the tumour as part of the generalized wate retention are reasons adduced for changes in pregnancy. What bearing the histological nature of the meningioma has on its biological behaviour during pregnancy remains a subject for speculation. Any increase in size in the angioblastic meningioma of our patient during her pregnancy was probably ue to engorgement of the vascular elements within the neoplasm. One of us (E. L. O has witnessed enlargement of intracrania aneurysms during pregnancy.-We are, etc.

Adelola Adeloye.

B. O. OSUNTOKUN.

E. LATUNDE OdeKu.

University College Hospital, Ibadan, Nigeria.

\section{Bilateral Parietal Thinning in Bronze Age Skull}

SIR,-Bilateral parietal thinning or biparietal resorption was noted on a female cranium recovered from Harappa (in West Punjab), which is the type-site of the Indus civilization belonging to the Bronze Age cultures and dated 2300 B.c. The age at death appeared to be about 45 years. This is probably the only reported palaeo-pathological case from the Indo-Pakistan subcontinent.

The cranium, which was unearthed from a regularly disposed burial at cemetery " $R$ 37," is otherwise normal and well preserved. It has two irregular large holes in each parietal bone. Examination has revealed that these holes are artificial and post-mortem breaks occurring at the sites of lesions causing depressions. These depressions are situated bilaterally and almost symmetrically. The thickness of the vault bones at different places beyond the margin of the lesions is on an average $6 \mathrm{~mm}$. From the outer margin of the lesions, where the normal bone thickness is retained, to the margin of the breakages, there is a decreasing gradient in thickness of the bone. This thinning was due to the migration of the outer table at the area of involvement, and the gradient was formed by gradual disappearance of the diploic surface before finally exposing the inner table just near the margin of the holes. It thus involved resorption of bone and a deposition of compact bony tissue along the surface. This condition of thinning is. by itself indicative that the woman had suffered from a lesion of a severe nature. This evidence and the specific localization suggest that it was a typical case of thinning of the parietals, which is not to be confused with other congenital anomalies located very near to the parietal foraminae. ${ }^{1}$

This condition was recognized on some ancient Egyptian crania by Smith. ${ }^{2} \mathrm{He}$ found those skulls having "strange, large symmetrical depressions of the parietal bones." 3 Rowling also noted this in the mummies of Thutmosis III and Meritamon of the New Empire period, and also in Khety from the middle kingdom. This abnormality has interested pathologists as a contemporary disease involving an atrophy of the parietals, usually accompanying old age. It has been concluded that it is a congenital dysplasia of the diploë of non-progressive type and a static nature of abnormality. ${ }^{5-7}$ Camp and Nash $^{*}$ reported 119 cases $(80$ males and 39 females), of which 10 were 30 years or less, one was a 4-year-old child, and another one was a 9-week-old infant. Examining 26 cases (19 females ranging from 54 to 86 years), Epstein ${ }^{3}$ concluded that this change is associated with post-menopausal and senile osteoporosis. A further attempt was made to reveal the cause of the disease, its peculiarity of localized susceptibility, and the role of osteoporosis and ageing in the thinning. Investigating only two patients, one a female of 85 years and another a male of 28 years, it was postulated that the thinning may be an acquired and progressive disease (progression was diagnosed in the female), and the localized thinning is explained in terms of decreased osteoblastic activity resulted from gonadal insufficiency, senility, or other causes of osteoporosis in a region where there is a little stress or strain."

It is apparent that this pathological change, the origin of which has been traced back to ancient civilizations, is not dependent on age or sex, but the exact cause is as yet not understood.-I am, etc.,

Pratap C. Dutta.

Anthropological Survey of India, Calan Museum,

REFBRENCES I Goldsmith, W. M., F. Hered., 1941, 32, 301. I. I. I, p. 46. New York.

Rowling, J. T., Proc. roy. soc. Med., 1961, 54,

Greig, $D_{.} M_{.,}$Edinb. med. F., 1926, 33, 645. 685. A. K., Amer. F. Roentgenol., 1944, 51, Camp, $\mathrm{J}$.

Epstein, B. S., Radiology, 1953, 60, 29. Steinbach, H.' L., and Obata, W. G., Amer. J.
Roentgenol., 1957, 78, 39.

\section{Dr. Thomas Percival and Jane Austen}

SIR,-When living in Southampton in 1808 Jane Austen sent a letter to her sister Cassandra in which she mentioned the arrival in the town of a new doctor-" We have got a new physician, a Dr. Percival, the son of a famous Dr. Percival of Manchester, who wrote moral tales for Edward to give to me."

This reference is of particular interest. Dr. Edward Percival was the eldest surviving son of Dr. Thomas Percival, whose book on medical ethics is a classic known to every doctor. Jane Austen was, however, referring to another of Dr. Percival's writings intended for young children. He married in 1767 and as his children were growing up he wrote a series of short tales, each illustrative of one of the moral virtues, so that the series demonstrated the harm produced by selfishness, untruthfulness, and the like. The first part was published in 1775, and later a second and third part were added to it. The Dictionary of National Biography states that this book " achieved great popularity," and we gather from Jane Austen's statement that her brother Edward gave her a copy when she was a little girl. The full title of the book was A Father's Instruction to his Children. Though we have no doubt that as a child Jane enjoyed reading the tales, we believe that the preface may have had more influence on her precocious mind, for in it are given the reasons why Dr. Percival wrote the book. They were three in number. Firstly, to inspire the young with a love of moral excellence ; secondly, to awaken curiosity and to convey in a lively manner knowledge of the works of God ; and, thirdly, to promote more early acquaintance with the use of words and ideas. 